\title{
CONTROL OF INTRAOPERATIVE SHIVERING UNDER SPINAL ANAESTHESIA- A PROSPECTIVE RANDOIMIZED COIMPARATIVE STUDY OF NALBUPHINE WITH TRAMADOL
}

KEY WORDS:

\section{Shivrambhai \\ Dhanabhai \\ Prajapati}

\section{Ankit Rajeshbhai Sorathiya}

\section{INTRODUCTION}

spinal anesthesia is a widely used technique for both elective and emergency surgeries. Shivering is one of the most commonly recognized complications of the central neuraxial blockade because of impairment of thermoregulatory control, reported in $40 \%-70 \%$ of the patients undergoing surgery under spinal anaesthesia. Post-anesthetic shivering is defined as an involuntary, spontaneous, rhythmic oscillating muscle hyperactivity that increases metabolic heat production up to $600 \%$ after anesthesia. Shivering during neuraxial anesthesia is a common issue that could have possibly adverse impacts, for example, increased oxygen consumption, carbon dioxide production, lung ventilation and cardiac work, as well as causing diminished mixed venous oxygen saturation. Spinal anesthesia impedes the thermoregulatory system by restraining tonic vasoconstriction which assumes significant role in the regulation of temperature.

Various methods are available for control of shivering; these may be non-pharmacological or pharmacological methods using drugs which have anti-shivering properties.

Tramadol $(0.5 \mathrm{mg} / \mathrm{kg})$ was found to be an effective treatment for shivering after intrathecal block. The intravenous (IV) administration of nalbuphine $(0.1 \mathrm{mg} / \mathrm{kg})$ provides a rapid and potent anti-shivering effect on post anesthesia shivering.

\section{Nalbuphine:}

semisynthetic opioid related to both naloxone and oxymorphine and has the characteristic of $\mathrm{u}$ receptor antagonist and kappa agonist activity. Nalbuphine has high affinity for k-opioid receptors in the central nervous system. Nalbuphine provide a rapid and potent anti-shivering effect.it is due to rapid onset of action, effective control, less recurrence rate.

Tramadol: is a centrally acting analgesic that has weak opioid agonist properties. tramadol also inhibits serotonin and norepinephrine uptake in the spinal cord and effective in treatment of intra-operative shivering after spinal anaesthesia.

This study is conducted to know the efficacy of nalbuphine versus tramadol in control of intraoperative shivering after spinal anaesthesia

\section{METHODS:}

After ethical committee clearance double blind, randomized controlled study was carried out at Anesthesiology department at Gujarat adani institute of medical sciences bhuj. 60 patients of ASA I and II patients belonging to either sex, aged between 18 and 65 years, undergoing elective orthopedic, lower abdominal surgery under spinal anesthesia were enrolled in the study. Patients who refused to participate or with neuromuscular diseases, psychological disorders, recent history of febrile illness, hypo or www.worldwidejournals.com hyperthyroidism, cardiopulmonary disease, an initial body temperature $>38^{\circ} \mathrm{C}$ or $<36^{\circ} \mathrm{C}$, a known history of alcohol or substance abuse, or receiving vasodilators and medications likely to alter thermoregulation were excluded from the study. Following a detailed pre-anesthetic examination, preoperative investigations including complete blood picture, renal function tests, liver function tests, and coagulation profile were sent and report assessed. All patients were premedicated with $0.25 \mathrm{mg}$ tablet of alprazolam the previous night of surgery. Informed written consent was obtained form the participants.

On arrival in the operating theatre, an intravenous line was opened with a 18G cannula in the dorsal aspect of either one of the hands. Lactated Ringer solution, warmed to $37^{\circ} \mathrm{C}$, was infused at $10 \mathrm{ml} / \mathrm{kg} / \mathrm{hr}$ over $30 \mathrm{~min}$ before spinal anesthesia. The infusion rate was then reduced to $6 \mathrm{ml} / \mathrm{kg} / \mathrm{h}$. Heart rate, mean arterial pressure (MAP), and peripheral oxygen saturation were recorded using standard noninvasive monitors before intrathecal injection and there after at $0,5,10$, $15,20,25$, and 30 minutes. Body temperature was monitored with a mercurial thermometer at the start of spinal anesthesia and during treatment of shivering. The temperature of the operating room was between $21-23^{\circ} \mathrm{C}$.

Patients were randomized into one of the group (Group $\mathrm{T}$ or Group N ). Group T would receive tramadol in a dose of 0.5 $\mathrm{mg} / \mathrm{kg}$ and Group $\mathrm{N}$ would receive Nalbuphan in a dose of 0.1 $\mathrm{mg} / \mathrm{kg}$. All the patients were assessed for shivering grades, its disappearance, hemodynamic status, and complications if any.

Neuraxial anesthesia was instituted at either L3-4 or L4-5 interspaces using three $\mathrm{ml}(15 \mathrm{mg})$ of hyperbaric bupivacaine $0.5 \%$ using a 25 gauge Quincke spinal needle, blocking up to T9-10 dermatome. Supplemental oxygen was given via a face mask at a rate of $4 \mathrm{~L} / \mathrm{min}$ during the operation. All patients were covered with one layer of surgical drapes over the chest thighs and calves during the operation and one cotton blanket over the entire body after the operation.

All cases were screened for shivering, if any, and graded with a Five point scale validated by Crossly and Mahajan.

\section{$0=$ No shivering}

l = Piloerection or peripheral vasoconstriction but no visible shivering.

2 = Muscular activity in only one muscle group.

$3=$ Muscular activity in more than one muscle group but not generalized.

$4=$ Shivering all over the body.

Gradation of Sedation was done as follow:

$0=$ Awake

$1=$ Drowsy

$2=$ Asleep but arousable

3 = Asleep but not arousable 
If shivering occurred, it was graded and recorded and 'antishivering agent' was given. If shivering persisted for 15 minutes at grade three or above, it was termed as 'severe shivering' and rescue treatment with the second dose of same amount of the same drug was done.

Side-effects such as nausea and vomiting and dizziness were recorded. If patient developed nausea and vomiting, metoclopramide $10 \mathrm{mg}$ was administered by intravenous route.

\section{Table : 1 Dermographic Data}

\begin{tabular}{|c|c|c|c|c|}
\hline & GROUP & GROUP & P & SIGNIFIC \\
T & value & ANCE \\
\hline $\begin{array}{c}\text { Age } \\
\text { (average) }\end{array}$ & $43.13 \pm 10.01$ & $40.55 \pm 9.67$ & 0.33 & NS \\
\hline Weight(kg) & $50.66 \pm 2.48$ & $49.9 \pm 4.64$ & 0.49 & NS \\
\hline Height(cm) & $165.033 \pm 6.18$ & $161.06 \pm 11.15$ & 0.09 & NS \\
\hline Male & $18(60 \%)$ & $20(66.66 \%)$ & & \\
\hline Female & $12(40 \%)$ & $10(33.34 \%)$ & & \\
\hline
\end{tabular}

Table 1 shows comparision of age,weight , height and gender distribution in both groups.

As $p$ value $>0.005$ which is not significant and both groups are comparable.

\section{Table: 2 Asa Grading}

\begin{tabular}{|c|c|c|c|c|}
\hline & tramadol & nalbuphine & Total & SIGNIFICANCE \\
\hline Asal & $20(66.66 \%)$ & $25(83.33 \%)$ & $45(75 \%)$ & $\mathrm{P}=0.528>0.005, \mathrm{NS}$ \\
\cline { 1 - 4 } Asa2 & $10(33.34 \%)$ & $5(16.66 \%)$ & $15(25 \%)$ & \\
\hline
\end{tabular}

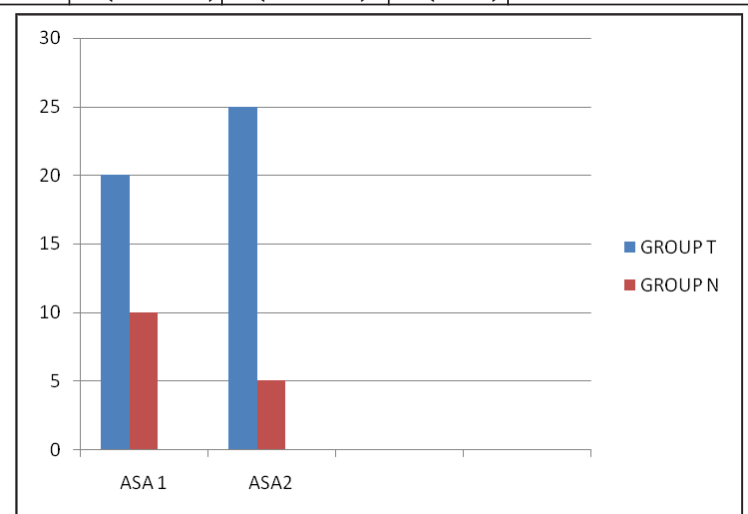

\section{CHART: 1 ASA GRADING}

Table 2 and chart 1 shows ASA Grade of patients in both groups. In group T ASA 1:ASA 2 ratio was 20:10. And In group $\mathrm{N}$ ratio was $25: 5$. $\mathrm{P}$ value was 0.528 , statistically not significant hence both group are comparable.

Table:3 Time For Onset Of Shivering

\begin{tabular}{|c|c|c|c|c|}
\hline Study group & $\begin{array}{c}\text { Onset } \\
\text { time }\end{array}$ & $\begin{array}{c}\text { Mean } \\
\text { difference }\end{array}$ & $\begin{array}{c}\text { P } \\
\text { value }\end{array}$ & Significant \\
\hline Group T ( $\mathrm{n}=30)$ & $20.5 \mathrm{mts}$ & $21.53 \%$ & $\begin{array}{c}0.068>0 \\
05\end{array}$ & $\begin{array}{c}\text { Not } \\
\text { significant }\end{array}$ \\
\hline Group N (n=30) & $22.6 \mathrm{mts}$ & & 05 \\
\hline
\end{tabular}

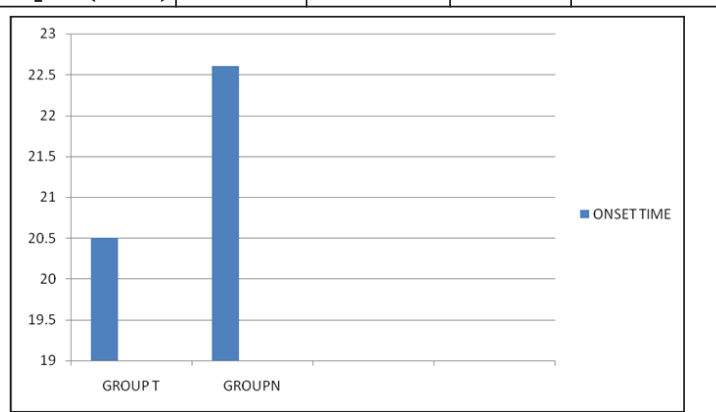

CHART:2 TIME FOR ONSET OF SHIVERING
Table 3 and chart 2 shows comparision of time for onset of shivering in both group as p value $0.068(>0.05)$ statistically not significant.

Table: 4 Comparision Of Mean Heart Rate

\begin{tabular}{|c|c|c|c|}
\hline TIME(MIN) & Group T (HR) & Group N (HR) & P Value \\
\hline 0 & $87.8 \pm 3.73$ & $89.96 \pm 3.04$ & $0.016>0.05$ \\
\hline 5 & $87.16 \pm 3.71$ & $85.76 \pm 2.31$ & $0.085>0.05$ \\
\hline 10 & $86.76 \pm 4.01$ & $88.13 \pm 3.32$ & $0.156>0.05$ \\
\hline 20 & $86.16 \pm 1.93$ & $85.53 \pm 3.24$ & $0.195>0.05$ \\
\hline 25 & $98.2 \pm$ & $98.2 \pm$ & $0 .>0.05$ \\
\hline 30 & $87.6 \pm 2.32$ & $88.06 \pm 3.80$ & $0.278>0.05$ \\
\hline 40 & $86.26 \pm 3.68$ & $85.9 \pm 2.79$ & $0.327>0.05$ \\
\hline 50 & $85.23 \pm 3.02$ & $85.96 \pm 3.97$ & $0.227>0.05$ \\
\hline 60 & $86.16 \pm 3.28$ & $86.3 \pm 3.79$ & $0.445>0.05$ \\
\hline
\end{tabular}

Table 4 shows no significant changes in heart rate in both group as Pvalue $>0.05$

Table: 5 Time Interval Of Disappearance Of Shivering

\begin{tabular}{|c|c|c|c|c|}
\hline Study group & Onset time & SD & P value & Significant \\
\hline Group T & 3.6 & 0.49 & $0.0017<$ & Highly \\
\cline { 1 - 3 } Group N & 3 & 0.870 & 0.05 & significant \\
\hline
\end{tabular}



Chart : 4 Time Interval Of Disappearance Of Shivering

Table 5 and chart 4 shows comparision of time interval of disappereance of shivering in both group which significantly shorter in group $\mathrm{N}$ compare to group $\mathrm{T}$ with $\mathrm{p}$ value 0.0017 ( $<0.05)$.

\section{Table:6 Side Effect}

\begin{tabular}{|c|c|c|c|c|}
\hline & Group T & Group N & Total & significsnce \\
\cline { 1 - 4 } nausea & $5(16.6 \%)$ & 0 & $5(8.33 \%)$ & \multirow{2}{*}{ NS } \\
sedation & $8(26 \%)$ & $30(100 \%)$ & $38(63.33 \%)$ & \\
\cline { 1 - 3 } Both & $2(6.6 \%)$ & 0 & $2(3.33 \%)$ & \\
\cline { 1 - 3 } Nill & $15(50 \%)$ & & $15(25 \%)$ & \\
\hline
\end{tabular}

Table 6 shows comparision of side effect in both group which is statistically not significant.

\section{DISCUSSION}

There are various methods available to control shivering during anesthesia, which include non-pharmacological methods and pharmacological methods using drugs which have anti shivering properties. In the present study, we compared the efficacy, potency and side effects of tramadol and nalbuphine in control of shivering after intrathecal block. Statistical analysis of collected data showed no statistical significance among demographic datas, age distribution and ASA grading between two groups. The onset of shivering between groups were with a mean difference of $21.53 \pm 2$ minutes. It showed no statistical significance between groups. The time interval for disappearance of shivering Group T with a mean time of $3.6 \pm 0.49$ minutes and Group $\mathrm{N}$ with a mean time of $3 \pm 0.87$ minutes. These results analysed by student $t$ test, were similar by the study of Usher Shukla et al. in 2011 [3], where they concluded tramadol good in controlling shivering, with significant side effects of nausea,vomiting and 
dizziness. The comparison of heart rate, systolic, diastolic, blood pressure respiratory rate, and mean Spo2 between groups showed no statistical significance which was similar to studies of Kranke P et al.in 2004 [4].

\section{CONCLUSION}

Both nalbuphine and tramadol are effective in treating patients with postspinal anesthesia shivering. time interval for complete cessation of shivering after treatment was significantly shorter with nalbuphine as compared to tramadol and tramadol causes significantly more nausea and vomiting and nalbuphine causes significantly more sedation

\section{REFERENCES}

1. Nirala DK, Prakash J, Ram B, Kumar V, Bhattacharya PK, Priye S. Randomized double-blinded comparative study of intravenous nalbuphine and tramadol for the treatment of postspinal anesthesia shivering. Anesth Essays Res 2020;14:510-4

2. Sriranganath T, Radhapuram SD, Rao MH, Shameem S, Samantaray A, Dharaniprasad G. Comparison of intravenous tramadol and intravenous ketamine for the prevention of post-anaesthetic shivering. J Clin Sci Res 2020;9:94-100

3. Usha shukla, kiran Malhotra, prabhakar t. A comparative study of the effect of clonidine and tramadol on postspinal anaesthesia shivering. 2011;55:3

4. Kranke P, Eberhart LH, Roewer N, Tramer MR. Single dose parentral Pharmacological intervention for the prevention of postoperative shivering; a quantitative systematic review of randomized controlled trials. Anaesth. Analg. 2004;99(6)718-727.

5. Sharma, M., Kharbuja, K., \& Khadka, B. (2017). Comparison of Pethidine and Tramadol for the Control of Shivering in Patients undergoing Elective Surgery under Spinal Anesthesia. Journal of Lumbini Medical College, 4(2), Surgery

6. Haque, M.F., Rashid, M. H., Rahaman, M. S., \& Islam, M. R. (2011). Comparison between tramadol hydrochloride \& nalbuphine hydrochloride in the treatment of per-operative shivering after spinal anaesthesia. Mymensingh medical journal :MMJ,20(2),201-205. 